\title{
ON LONELINESS AND THE VALUE OF SLOW REFLECTION
}

Author:

Karin van Marle

Affiliation:

${ }^{1}$ Department of Legal

History, Comparative Law

and Legal Philosophy,

University of Pretoria,

South Africa

\section{Correspondence to:}

Karin van Marle

e-mail:

karin.vanmarle@up.ac.za

Postal address:

Department of Legal

History, Comparative Law and Legal Philosophy, Faculty of Law, University of Pretoria, Pretoria, 0083, South Africa

\section{Keywords:}

reconciliation; slowness;

common sense; Arendt

transformation

\section{Dates:}

Received: 21 Aug. 2009

Accepted: 06 Oct. 2009

Published: 16 Dec. 2009

How to cite this article: Van Marle, K., 2009, ‘On loneliness and the value of slow reflection', Verbum et Ecclesia 30(2), Art. \#338, 4 pages. DOI: $10.4102 /$ ve.v30i2.338

\section{This article is available} at:

http://www.ve.org.za

Note:

This is a reworked version of a paper delivered at a conference What is law without morality? at the University of the Western Cape in August 2007 hosted by the Department of Religion and Theology and the Ecumenical Foundation of South Africa in consultation with the Faculty of Law. My gratitude to the organisers for the opportunity. My thanks also to the anonymous referees for their insightful comments. Any mistakes do, of course, remain my own.

(C) 2009. The Authors. Licensee: OpenJournals Publishing. This work is licensed under the Creative Commons Attribution License.

\section{ABSTRACT}

In this article, the author considers the relationship of law, morality and reconciliation. Intrigued by the political and ethical stances taken by Arendt and McCarthy, the author supports notions of detachment, slowness and social reconciliation concerning contemporary political and ethical questions.

\section{INTRODUCTION}

The broader concern of this article is to question our response to social ills in times where morality, ethics and normative considerations are subsumed day by day not only by claims for logic and rationality but also by instrumental, functional and pragmatic strategies. I reflect on notions of loneliness, slowness and social reconciliation in order to continue conversations and contemplations on the relations between law and morality or, rather, between law and ethics, reconciliation and transformation.

I start by drawing on an article written by Deborah Nelson, in which she investigates the politics and ethics followed and lived by Hannah Arendt and her friend Mary McCarthy (Nelson 2006:1). Arendt and McCarthy, in contrast to the post-war calls for solidarity and community, firmly embraced loneliness and detachment as more apt responses to the political, social and ethical problems of their time. I connect their stance with an earlier call for slowness as an 'ethical' approach to law (Van Marle 2003:239). I also discuss an argument for slowness by Paul Cilliers within the context of complex-systems theory (Cilliers 2007). I conclude with reference to Mahmood Mamdani's call for social reconciliation (Mamdani 1998). The argument tentatively sets out social reconciliation as an engagement with ordinary lives that will inevitably be slower, more attentive and less grandiose and monumental.

\section{LONELINESS AND DETACHMENT, COMMON SENSE AND FACTS - SLOW REFLECTIONS}

As already noted, my concern is how the law, legal theory and jurisprudence could respond in an ethical and political manner to the severe social problems that people encounter in their everyday lives or, to use the familiar terms, how law could respond to social justice - in Mamdani's words, 'social reconciliation'. I should explain from the start my understanding of and engagement with the term 'social'. With 'social', I do not mean merely issues of economic concern but also issues that concern a sociality, the living together of plural people. Against this background, I am intrigued by the stance of loneliness and detachment taken by Hannah Arendt and her friend Mary McCarthy.

Deborah Nelson, in the article The virtue of heartlessness: Mary McCarthy, Hannah Arendt, and the anaesthetics of empathy, discusses the friendship between Hannah Arendt and Mary McCarthy and uses the idea of 'being alone' and on the 'same side' to describe their relationship (Nelson 2006:1). She argued that the 'detached quality of relation', which was a feature of their friendship, also guided their political and ethical affiliations. Both Arendt and McCarthy defy easy categorisation concerning their political commitments but their 'mode of relation' also placed them in a peculiar position vis-àvis their potential allies (Nelson 2006:2). Nelson states that, within the post-war context, progressive social movements called for solidarity, 'bonds of intimacy and group identification' (Nelson 2006:2). Arendt and McCarthy, however, refused these stances in theory and in practice in their preference for solitude over solidarity and for detachment. Arendt's critique on compassion in political life, which she regarded as 'devastating', was at the core of her work On revolution (Arendt 1960).

Nelson highlights the two extreme responses to pain that we all experience in our daily confrontations with the media and the social ills of our times: The one response leads to the situation 'where pain supplies an overabundance of meaning or stimulation' and the other to one 'where it fails to produce any affective response at all' (Nelson 2006:2). Arendt and McCarthy did not follow either of these two responses. Instead, they acted in a manner that Nelson names 'toughness' (Nelson 2006:2). They did not shy away from suffering but were wary of being drawn into a discourse that makes it 'attractive' (Nelson 2006:2). Instead of being indifferent or callous, they wanted to face 'reality' without being consoled by intimacy, empathy or solidarity, which they regarded as having a potential 'anaesthetic' effect (Nelson 2006:2-3). Arendt rejected notions of friendship that relied on intimacy as well as notions of national belonging, ideological partisanship and party politics. Nelson explains that, apart from solidarity's potential anaesthetic effect, it also holds the danger of coercion and exclusion. The insulation of it comes in forms such as national belonging, which protects individuals against the 'loneliness and isolation of mass society'; ideological solidarity, which prevents unpredictability by putting in place a 'coherent theory of experience and shared narrative of the future'; and the solidarity of pariah groups, which provides a togetherness 'found nowhere else in modern society' (Nelson 2006:4). The last-mentioned position comes to the fore in Arendt's work on Rahel Varnhagen, whom she criticised for her lack of 'worldliness' (Arendt 1957). Arendt associated a loss of worldliness with a loss of common sense, a matter on which I shall elaborate.

Arendt and McCarthy insisted on the 'ordinariness' of pain and suffering. Nelson phrases their stance as one of, instead of coming face to face with the Other, coming 'face to face with reality in the presence 
of others' (Nelson 2006:3). They had two reasons for requiring 'facing reality': Firstly, to reject the self-delusion that follows from the reluctance to look directly at pain and suffering and, secondly, because facing reality could set in motion processes both of transformation and of self-transformation, which are conditions for any form of social change (Nelson 2006:3). Another important reason is that such self-transformation could bring a person uncertainty and anxiety. The features of uncertainty and anxiety recall Gillian Rose's reliance on Arend (together with Luxemburg and Varnhagen) as women who lived in unequivocation and risk (Rose 1992). Nelson describes Arendt's choice of facing reality in terms of her reliance on what she regarded as 'common sense' and McCarthy's on what she regarded as 'facts'.

'Common sense' for Arendt, as we have seen, is connected to being in the world. It has nothing to do with obvious, 'self-evident and natural truths' but rather with an 'active and complex sharing of a necessarily partial view of the world' (Nelson 2006:3-4). The modern emphasis of logic, according to Arendt, is quite useless as far as matters of the world are concerned. She supported a 'restoration of the sensual component of common sense' (Nelson 2006:5). Her support of common sense is closely connected to her call for political action - common sense is activity, not knowledge (Nelson 2006:5). Importantly, common sense is part of self-becoming, of the process of self-transformation, of changing beliefs, views and positions. Pariahs, who act only with others like themselves, can never partake in these processes of becoming or what Arendt called 'refinement' (Nelson 2006:5). Plurality is, of course, central to Arendt's political understanding - to bring the 'self into contact with non-intimate others' (Nelson 2006:5; see also Arendt 1958). We can recall Arendt's description of Adolf Eichman - his evil as banality and thoughtlessness rather than as a failure of empathy (Arendt 1963). Nelson notes two requirements for common sense learned from Eichman's example, namely difference and language (Nelson 2006:6). In these two requirements - or facts - Arendt's theory connects with McCarthy's literary writing and her notion of facts. For McCarthy, facts do not represent 'a faith in objective and stable reality but a confrontation with reality's elusive, sensual, and frequently painful qualities' (Nelson 2006:4).

Nelson regards fact and factuality as the foundation of McCarthy's aesthetics, as it was a foundation to Arendt's politics (Nelson 2006:6). Facts are aesthetic, something that one requires by way of cognition, not knowledge. McCarthy highlighted the difficulty of achieving facts through cognition in her times and criticised her contemporaries for retreating from traumatic events and embracing the realism of pure 'sensation' and 'sensibility', thereby 'abolishing the social' (McCarthy 1961:276; Nelson 2006:7). She declared:

To find the ideal realist, you would first have to find reality . And if no dramatist today. . . can accept being a realist in its full implications, this is perhaps because of a lack of courage.

(McCarthy 1961:311; Nelson 2006:7)

Nelson notes that McCarthy's understanding of a fact is relatively difficult - she clearly does not mean pure information, although, in some cases, it can be that. A fact can, for example, refer to a historical event (such as the death camps) or a cultural one (such as a new art form or artist) or to an aesthetic object (such as a painting). It is easier, according to Nelson, to understand what a fact (for McCarthy) does. Like Arendt's common sense, a fact is less concerned with providing information than with its capacity to change the observer. McCarthy criticised the absence of facts in American life - she argued that, although there was enough opinion and even critical opinion, there was no diversity of opinion or truly dissident ideas; the reason for this was the general fear of confronting facts. Writers were more interested in 'displaying their cleverness than contending with facts' (Nelson 2006:7). She called for 'yielding' to facts, by which she meant being 'open to alteration which is genuinely painful' and asked for intellectuals to 'in place of cleverness' 'risk perplexity and lack of mastery' (Nelson 2006:8). This entails embracing a continuous process of 'self-alienation' (Nelson 2006:8). The dissident potential of the fact is connected to the 'accident', the 'unexpected', 'the surprise', 'the miracle' in everyday experience. Herein lies another connection with Arendt, namely Arendt's insistence on unpredictability, natality and new beginning (Nelson 2006:11).

Nelson concludes with reference to McCarthy's eulogy to Arendt. In describing their friendship, McCarthy chose to emphasise the limits of and 'the need for space' that comes with intimacy (Nelson 2006:11). In this understanding of friendship, attachment 'has to be refused on principle' (Nelson 2006:11). The bearing that this view of friendship then has on politics is that the heartlessness that is so preservative of friendship is also a precondition for public life. As Nelson argues, this should be regarded not simply as insensitivity but rather as a call to re-sensitisation, 'not to look away, but to look hard' (Nelson 2006:11-12)

\section{SOCIAL RECONCILIATION AND TRANSFORMATION AS SLOWNESS}

I have previously argued for slowness as an approach to legal interpretation but also as an approach to law more generally (Van Marle 2003:239). The argument is that with slowness could come greater attention to particularities. With references to reflections on language and memory, I raised the possibility of a slower contemplation going hand in hand with a material recollection, an approach that could be embedded and situated within a context in contrast to law's tendencies to generalise and universalise.

I have subsequently also connected slowness and, particularly, material recollection with what Lourens Du Plessis called the 'memorial constitution' (Du Plessis 2000:63). Memorial constitutionalism, in contrast to monumental constitutionalism, holds the potential of being more aware of history, of the role of memory in post-apartheid law and, importantly, of being more aware of its own limits, its own impossibilities. Slowness as an approach to law means an approach that calls for more reflection and contemplation. It is, from the outset, an approach concerned with ethics, with law and with the precarious relationship between law and ethics. Relating these ideas to Arendt and McCarthy, one could say that slowness is less concerned with gestures of solidarity and more with Arendtian common sense and with what McCarthy referred to as facts. As an ethical approach, it is concerned with 'looking hard' without being tempted by grand gestures of monumental constitutionalism, nation building and political reconciliation.

Paul Cilliers, in a reflection on slowness within the context of complex-system theory, argues that 'a slower approach is necessary not only for survival, but also because it allows us to cope with a complex world better' (Cilliers 2007:1). He explains that our understanding of time has been distorted by the rational and instrumental theories of the modern world and by the effects of certain technologies. He makes a few important remarks pertaining to slowness. One of these is an argument for slowness not being a conservative one. It is not merely backward-looking or a glorification (monumentalisation) of what has been. It does show concern with the historical nature of knowledge and memory but it is also, simultaneously, forwardlooking. It is, in itself, a temporal notion in contrast with a static notion (Cilliers 2007:1). He argues that slow and fast might not be the correct terms and that terms such as 'reflective' and 'unreflective', 'mediated' and 'unmediated' might capture the argument better.

Cilliers refers to Bauman's reflections on time and explains the aim of instrumental rationality to create conditions of certainty in which we can escape contingency. In order to do this, we need to understand and, more importantly, control 
the future: 'Modernism becomes a project which demands our total commitment against the forces of irrationality and chaos' (Cilliers 2007:2). Modernism influences our conceptions of time in two ways. Firstly, it attempts to coordinate our actions by universalising time as if 'we all live in the same time'. Technology, particularly clocks, has made this possible; time has been synchronised and we have to live our lives according to a 'generalised and controlled understanding of time' (Cilliers 2007:3). Secondly, it results in the desire to control the future, to make it knowable. As Cilliers explains, this is possible only if we could perpetuate the present, if we lived in an eternal present, in 'the tyranny of the moment' (Cilliers 2007:3).

A further step in this development is the phenomenon of immediacy. Because an immediate response is always available, the delay associated with reflection is unacceptable. Cilliers refers in this regard to Derrida's notion of différance as a way of undermining the metaphysics of presence (Cilliers 2007:3; see also Derrida 1978). Différance combines two meanings, namely difference as a spatial notion and delay as a temporal notion, with the result that the present consists only as a combination of memory (of what has been) and anticipation (of what is to come)' (Cilliers 2007:3). Memory is explained as 'something embodied in the system' and not as something abstract - '. . . the system is its memory' (Cilliers 2007:4). Memory is not, however, merely a process of accumulation. It is also the result of a process of selection. It is furthermore possible only if the system can also forget. And it is 'not an instantaneous thing, it takes time to develop, it is slow' (Cilliers 2007:4). Returning to Arendt and McCarthy and their response of loneliness and detachment to the social woundedness of their time, it is important to consider responses to the social ills of post-apartheid South Africa. Continuous socio-economic inequality, poverty, homelessness and a lack of health care, food, water and education permeate life in post-apartheid South Africa. Added to these socio-economic problems is the continuous drive for grand 'political' gestures and for the private enrichment of a minority of individuals to the detriment of the majority of the South African population. It is therefore not merely the socio-economic context that is at stake but also - and, in fact, integrated with the former - the absence of a vibrant public realm where, in Arendt's terms, people can appear to each other.

It is useful to recall Mahmood Mamdani's critical reflection on the South African Truth and Reconciliation Commission (TRC) and its ideal of creating a common society in which new and common identities could be formed so that both victims and perpetrators could live together (Mamdani 1998). Mamdani argues that (to a certain extent) 'political reconciliation' in South Africa has been achieved. The big challenge, however, is how to make this reconciliation durable. What must be added to Mamdani's critique of the TRC is the inevitable connection between the ideals of the TRC and post-apartheid law, specifically the notion of constitutionalism and human rights. The TRC and its ideals of national unity and reconciliation did, after all, have their origins in the epilogue of the 1994 Constitution. A critique of the TRC process and, more pertinently, the lack of social reconciliation and social justice is therefore also a critique of the constitutional endeavour.

Mamdani is concerned with how the difference between perpetrator and beneficiary has become obscured in the South African reconciliation process (Mamdani 1998). The 'truth' sought and the reconciliation 'achieved' was to the benefit of the minority, to the exclusion of the majority of people who suffered under apartheid. The minority in the South African context includes perpetrators, people who were part of or closely connected to the previous regime and those political activists who were directly involved in the struggle and persecuted by apartheid officials. The majority of white South Africans, although they were not directly involved in the institutional workings of apartheid, nevertheless benefited; similarly, the majority of black South Africans were not directly involved in the struggle but suffered under apartheid's systemic oppression and discrimination.

Mamdani's call is for a shift from perpetrators to beneficiaries and from activists to victims, so that social reconciliation and social justice can be addressed (Mamdani 1998). This shift would expose apartheid as a system of white privilege. People who suffered systemic violations, such as pass laws and forced removals, and who remained anonymous, their suffering seemingly circumstantial, would benefit from this shift, as their suffering currently remains unnoticed. Mamdani explains that this shift would require a shift in logic: Perpetrators are personally and individually guilty; beneficiaries are not necessarily linked to individual agency (Mamdani 1998). In order truly to challenge the continuance of past privilege and oppression, the question of individual agency should not be used to negate responsibility and, as a consequence, stand in the way of redress.

For me, Mamdani's call for social reconciliation resonates with the concerns raised by Arendt and McCarthy. Focus on and preoccupation with grand narratives and with the ideals of group solidarity and 'political' reconciliation as used by the TRC to address ethical concerns of suppression, discrimination, poverty and exclusion only hinder real reflective engagement with change. Arendt's insistence on common sense and McCarthy's on facts, however, provide a suggestive way of approaching the issue of social reconciliation raised by Mamdani.

It is well known that Arendt criticised the French Revolution for being overtaken by bread-and-butter issues to the detriment of political freedom (Arendt 1960). It is for this reason that she praised the American revolution. If Mamdani were calling merely for a programme of socio-economic reform, he would be in exact opposition to Arendt. My interest is to see connections between the two stands, albeit, at a first read, they seem to be conflicting or, at the least, in tension with each other.

The very (im)possibility of reconciliation must, of course, be considered. Social reconstruction, development and upliftment can be programmed and measured to a certain extent. Reconciliation, however, will always stand within the gesture of an event - it is unpredictable and may happen only because of human appearance and the trait of natality. When contemplating reconciliation, we immediately think about more than one party - it takes two to reconcile, as it were.

Arendt's stance for loneliness and detachment was by no means a total rejection of sociality. Her critical engagement with Rahel Varnhagen, who appeared 'worldless' and who sought the comfort of group solidarity, underscores her (Arendt's) affinity for the world, for being active in a public realm where human plurality could come to the fore. This is not a sociality that is based on hegemony and heteronormative values, where, as Drucilla Cornell aptly notes the 'heteros' has been erased to serve only the being of one (Cornell 2007). When Arendt emphasised common sense, it was exactly the sensibilities of the world, of being part of a public, that were of concern. Having such common sense, however, would be possible only through the ability to detach, to stand alone in order to prevent a mere following of the herd mentality or of business as usual. Mamdani criticises the TRC's 'political' reconciliation for not following common sense, for not serving the world, but for fulfilling narrow strategic, economic motivations.

The project of constitutionalism and human rights in postapartheid South Africa is, in many instances, the suggested framework from which to address many of the dilemmas facing us. Like the TRC, however, this project could have only limited success. My suggestion is that this project could benefit through the consideration of an approach of slowness and through the stances of loneliness and detachment lived by Arendt and McCarthy. The embrace of slowness, loneliness and detachment could heed the optimistic, quick and grand gestures associated 
with the constitutional and human rights discourse. With respect to reflection on reconciliation, the aim should be to achieve more than has been achieved until now - what Mamdani calls 'social reconciliation' must be embraced. This is not social reconciliation focused only on socio-economic reform - in other words, socioeconomic reparation and reconstruction - but reconciliation aimed at the ongoing construction of an active public sphere and at the becoming of a sociality that truly reflects plurality.

\section{REFERENCES}

Arendt, H., 1957, Rahel Varnhagen. The life of a Jewess, John Hopkins University Press, London.

Arendt, H., 1958, The human condition, University of Chicago Press, Chicago.

Arendt, H., 1960, On revolution, Penguin Books, London.

Arendt, H., 1963, Eichman in Jerusalem, Penguin Books, London.

Arendt, H., 1978, Writing and difference, Routledge, London/New York.

Cilliers, P., 2007, On the importance of a certain slowness. Stability, memory and hysteresis in complex systems 1-8, viewed 10
November 2007, from http://complexity.vub.ac.be/phil/ drafts/Cilliers.pdf. Also published in C. Gershenson, D. Aerts \& B. Edmonds (eds.), Worldviews, science and us: Philosophy and complexity, pp. 53-80, World Scientific, Singapore.

Cornell, D., 2007, 'The shadow of heterosexuality', Hypathia 22, 229-242.

Du Plessis, L.M., 2000, 'The South African constitution as memory and promise', in C. Villa-Vicencion (ed.) Transcending a century of injustice, pp. 63-94, Institute for Justice and Reconciliation, Cape Town.

Mamdani, M., 1998, When does reconciliation turn into a denial of justice? HSRC Press, Pretoria.

McCarthy, M., 1961, On the contrary: Articles of belief, 1946-1961, Farrar, Straus and Cudahy, New York.

Nelson, D., 2006, American literary history 18, 86-101, viewed 15 July 2007, from http://allh.oxfordjournals.org/cgi/content/ full/18/1/86 1-14.

Rose, G., 1992, In a broken middle, Blackwells, Oxford.

Van Marle, K., 2003, 'Law's time, particularity and slowness' South African Journal on Human Rights 19, 239-255. 